\title{
UVODNIK
}

\section{VOJAŠKO ZNANJE V SODOBNEM VARNOSTNEM OKOLJU}

V tretje desetletje izhajanja Sodobnih vojaških izzivov vstopamo v znamenju 15. obletnice slovenskega vstopa v elitni mednarodni združenji Evropsko unijo in zvezo Nato. Slednji velja še posebna pozornost, saj obstaja že 70 let. Tej mednarodni politični in vojaški organizaciji se je Republika Slovenija pridružila leta 2004. Posebna tematska številka $\mathrm{z}$ naslovom 15 let $v$ zavezništvu bo izšla $\mathrm{v}$ začetku septembra kot tretja letošnja številka. Rok za oddajo člankov je 17. maj 2019.

Druga številka v tem letu je namenjena strateškim komunikacijam in oboroženim silam. Obe tematski številki bosta izšli v angleškem jeziku, saj želimo z omenjenima vsebinama doseči čim večji krog bralcev, strokovnjakov in znanstvenikov.

Zadnja, četrta, številka v 21. letniku bo namenjena organizacijski klimi, in sicer predvsem v oboroženih silah, rok za oddajo člankov pa je 8. avgust 2019.

V letošnji prvi številki se posvečamo vojaškemu znanju v sodobnem varnostnem okolju. Jeseni 2017 se je začelo generalštabno šolanje pripadnic in pripadnikov Slovenske vojske. To je bila že osma generacija generalštabnega šolanja v zgodovini Slovenske vojske in samostojne države. Slušatelji so usposabljanje končali v začetku oktobra 2018 s slovesnostjo v Centru vojaških šol. Nekateri med njimi so se odločili za objavo članka v Sodobnih vojaških izzivih.

Vojaško znanje je bilo prvo v zgodovini institucionalizacije znanj razen teologije, ki jo je prvotno cerkev razvijala sama. Med vojaške šole z najdaljšo tradicijo uvrščamo lizbonsko vojaško akademijo, ki je bila ustanovljena leta 1641. Litvanska vojaška akademija je bila ustanovljena leta 1747 na pobudo generala Jonasa Žemaitisa. Terezijanska vojaška akademija v Avstriji velja za najstarejšo vojaško akademijo v Evropi. Ustanovila jo je Marija Terezija leta 1751. Na Nizozemskem imajo Kraljevo vojaško akademijo od leta 1826. Kraljeva vojaška akademija v Belgiji je 
bila ustanovljena 1834. Nacionalna obrambna akademija je naslednica Kraljeve in imperialne vojaške šole, ki jo je 1852 ustanovil avstrijski cesar Franc Jožef.

Začetek organiziranega izobraževanja in usposabljanja v Slovenski vojski sega $\mathrm{v}$ leto 1991, ko je bila 16. decembra ustanovljena prva vojaška šola v samostojni državi, Šola za podčastnike. Delovala je v sestavi izobraževalnega centra Ministrstva za obrambo.

Leta 1993 so se Šoli za podčastnike pridružile še Poveljniško-štabna šola, Šola za častnike in Šola za častnike vojnih enot. Leta 1995 so izobraževalni center preimenovali v Center vojaških šol, ki je leta 1999 postal sestavni del Slovenske vojske. Da bi povezali vojaško izobraževanje in usposabljanje z znanstvenoraziskovalnim delom na področju vojaške znanosti in doktrin ter tako dali možnost neposrednega uvajanja novega vojaškega znanja skozi šolski sistem v prakso, sta se leta 2004 v Poveljstvo za doktrino, razvoj, izobraževanje in usposabljanje (PDRIU) povezala Center vojaških šol in Delovna skupina za doktrino in razvoj. PDRIU je leta 2007 preselil svojo dejavnost iz prostorov v ljubljanskem Šentvidu na Tabor v Maribor, v Vojaški objekt Kadetnica. Njena zgodovina sega v čas reformiranja avstrijske vojske, ki se je začelo leta 1848. Novembra 1918 je na predlog generala Rudolfa Maistra novi poveljnik vojaške realke postal Slovenec podpolkovnik Davorin Žunkovič. Tako se je 3. decembra 1918 začel pouk na prvi slovenski vojaški šoli in je potekal v slovenskem ter srbohrvaškem jeziku. Žal je to trajalo le kratek čas.

Po letu 2004, ko smo postali polnopravni člani Evropske unije, se je tudi na področju vojaškega izobraževanja, usposabljanja in izpopolnjevanja veliko spremenilo. Okrepila se je mednarodna izmenjava vojaškega znanja v najrazličnejših oblikah. Izmenjava slušateljev in predavateljev med oboroženimi silami je najosnovnejša oblika sodelovanja na tem področju, sledi izmenjava dobrih praks in skupno delovanje na vojaških vajah, kar je priprava za skupno delovanje v mednarodnem varnostnem okolju ali, konkretneje, v mednarodnih operacijah in na misijah. Delovanje na predstavništvu države $\mathrm{v}$ mednarodnih organizacijah in delovnih telesih je posebna preizkušnja teoretičnega znanja in prakse. Pisanje kompleksnih znanstvenih in strokovnih besedil pa velja za bolj žlahten način izkazovanja znanja, prakse, razgledanosti in načina mišljenja avtorja.

V Slovenski vojski se besedila slušateljev različnih vojaških šolanj najpogosteje pojavljajo v Vojaškošolskem zborniku, ki je namenjen prav temu. Leta 2018 je izšla že 13. številka zbornika, kar kaže na to, da je v slovenskem vojaškem kadru še vedno potencial za poezijo in prozo, ki ga je v začetku prejšnjega stoletja izkazoval že general Rudolf Maister. Generalštabno šolanje je najvišja raven v hierarhiji vojaškega šolstva, zato smo se odločili, da prvo letošnjo številko namenimo predvsem vsebinam člankov, ki so jih napisali slušatelji zadnje generacije.

Slovenska vojska do leta 2025 in naprej je naslov članka Franja Lipovca. V prispevku se je osredotočil na Natovo metodologijo, imenovano DOTMLPFI, s katero je poiskal prednosti in pomanjkljivosti Slovenske vojske ter predlagal 
priporočila za delovanje Slovenske vojske v prihodnosti na področju konsolidacije sistema, priprave vizije, povezovanja, posodobitve in fleksibilnosti strukture enot ter finančne stabilnosti in vzdržnosti.

\begin{abstract}
Aleksander Vidergar piše o Vlogi Slovenske vojske pri uresničevanju zunanjepolitičnih interesov in ciljev Republike Slovenije. Proučuje strateške dokumente države in ugotavlja, v katerih je ali ni omenjena Slovenska vojska ter v povezavi s katerimi zunanjepolitičnimi interesi in cilji. Slovenska vojska je precej aktivna v mednarodnem varnostnem okolju. Njen prispevek je še posebno cenjen v Evropski uniji in zavezništvu v obdobju po letu 2004 s sodelovanjem v različnih mednarodnih operacijah in na misijah. Več o tem, kako Slovenska vojska prispeva k uresničevanju zunanjepolitičnih interesov in ciljev države ter kako bi še lahko prispevala, si preberite $\mathrm{v}$ članku.
\end{abstract}

V migrantski krizi leta 2015 je sodelovala tudi Slovenska vojska. O njeni umeščenosti v krizno odzivanje in o izkušnjah piše Boštjan Novak v članku z naslovom Vloga Slovenske vojske ob pojavu kompleksne krize v Republiki Sloveniji. Migrantska kriza v obsegu iz leta 2015 je mimo. Veliko smo se naučili in prav je, da te izkušnje upoštevamo tudi $\mathrm{v}$ prihodnje $\mathrm{v}$ strateških dokumentih države, pri načrtovanju in organiziranosti nacionalnovarnostnega sistema ter na drugih področjih.

Bogomir Tomažič meni, da je 25. obletnica začetka delovanja mornariške enote SV mejnik, ki zahteva, da temeljito premislimo in načrtujemo nadaljnjo pot rodu, da bi v razmerah omejenih kadrovskih in finančnih virov ob ustrezni politični podpori ter s sodelovanjem na nacionalni in mednarodni ravni ohranjal sposobnosti za izvajanje poslanstva in nalog oziroma jih še nadgrajeval in zagotovil še boljšo vpetost ter prepoznavnost kot gradnik pomorske varnosti RS. Kako doseči ta cilj, je napisal v prispevku Razvoj pomorstva Slovenske vojske in uresničevanje obrambne strategije Republike Slovenije.

Sodelovanje Slovenske vojske v sistemu helikopterske nujne medicinske pomoči je članek avtorja, ki pri reševanju z vojaškim helikopterjem osebno sodeluje. Igor Lanišnik predlaga nekaj sprememb v sistemu zagotavljanja helikopterske nujne medicinske pomoči, tako da bi bilo usklajevanje med Slovensko vojsko in Policijo čim učinkovitejše. Zagotavljanje te pomoči je v Republiki Sloveniji urejeno nekoliko drugače kot v drugih državah, kar je svojevrsten izziv.

Zračnodesantna zmogljivost je dobra, pravi Viktor Potočnik, ker so njeni pripadniki izpostavljeni strožjemu izboru in privlačijo bolj motiviran ter kakovostnejši kader s statusom, ki ga predstavljajo. Ta status je spet povezan z zahtevnim usposabljanjem in izborom. Da bi razvili visok esprit de corps, ki se upravičeno pripisuje zračnodesantnim enotam, niso nujni padalski skoki in specialna oprema. Kaj je še potrebno, lahko preberete v članku Zračnodesantne zmogljivosti in Slovenska vojska. Avtor tega članka je edini v tej številki, ki ni bil slušatelj zadnje generacije generalštabnega šolanja. 
Liliana Brožič

Bralce Sodobnih vojaških izzivov vabimo $\mathrm{k}$ branju pridobljenega vojaškega znanja avtorjev ter $\mathrm{k}$ prispevanju svojih idej in pogledov. $\mathrm{V}$ pomoč pri pisanju naj vam bodo navodila avtorjem na koncu publikacije. 